\title{
Indledning
}

\section{Just a Freudian Slip?}

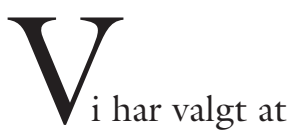

udgive et temanummer, der fokuserer på psykoanalytiske forståelser af køn eller på brug af psykoanalyse til at forstå køn, som det fremstår i konkrete fænomener. Hensigten har været, at undersøge nogle af de udviklinger psykoanalytisk forståelse af køn og kønnede handlinger har gennemløbet i de senere år, hvor poststrukturalistiske tilgange har domineret feltet.

I kønsforskningens tidlige år i 70erne havde psykoanalysen en vigtig funktion, både som medspiller og som modspiller. Mange kvindeforskere vendte sig kritisk imod de meget stivnede og deterministiske tolkninger af psykoanalysens kønsforståelse, ikke mindst der, hvor psykoanalysen, i strid med sig selv, havde gjort de fundne kønskonstruktioner til normative retningslinier. Selvfølgelig stod Freuds opfattelse af penismisundelse for skud, men det gjorde den jo allerede i psykoanalysens tidligste dage, hvor flere kvindelige psykoanalytikere pegede på de reale livsvilkårs betydning for kvindelighedens dannelse.

Nogle kønsforskere valgte i 70erne helt at afskrive psykoanalysen som brugbart redskab til at forstå kønnede forhold - her blev psykoanalysen set som en del af det patriarkalske kompleks der skulle bekæmpes, fordi det blev brugt til at fastholde mænd og især kvinder i stereotype mønstre. Her var der da også nogle få psykoanalytikere der stillede sig til rådighed som projektionsobjekt for denne vrede.

Andre kønsforskere valgte at fortsætte det arbejde, der allerede var startet, med at tolke psykoanalysens kønsforståelse ud af den biologiske determinisme, som Freud arbejder kan forstås som. Her opstod der en mangfoldighed af forskellige psykoanalytiske perspektiver på køn. Inden for litteraturvidenskaberne var det især tolkninger, der tog udgangspunkt i Lacans arbejder, der udviklede sig, inden for pædagogikken var det især objektrelationsteoretiske tolkninger og i psykologien udvikledes kritisk teoretiske tilgange samtidig med at mere traditionelle psykoanalytiske forståelser arbejdede videre med at vikle den Freudske forståelse ud af det, nogle har kaldt Freuds selvmisforståelser.

$\mathrm{Nu}$ hvor kønsforskningen synes at blomstre på ny, er det især de poststrukturalistiske tolkninger af kønnede relationer, der tegner billedet, og da det meste af den anderledes orienterede kønsforskning har ligget underdrejet i nogle år, kommer de poststrukturalistiske forståelser til at stå ret alene. Men hvor andre teoretiske tilgange til forståelse af menneskers liv, handlinger og relationer kan "glemme" at forholde sig til kønnet, ligger det i psykoanalysens "natur", at det ikke er muligt. Så skønt de psy- 
koanalytiske forståelser har været mindre eksponeret i offentligheden i en periode, betyder det ikke at udforskningen af køn ikke er fortsat her.

Det er derfor vi i dette nummer af Kvinder, Køn \& Forskning har vendt os mod psykoanalysen igen, for at se hvor dens kønsforståelse har udviklet sig hen og hvordan den møder den poststrukturalistiske udfordring.

Tid og sted er altid vigtigt, så dette temanummer spiller ud med et essay, hvor Morten Thing beskriver psykoanalysens fremkomst i Danmark i 30erne; hvordan den blev mødt og brugt og hvilken betydning Freuds tanker, som de blev formidlet herhjemme, fik for den seksualpolitiske bevægelse. Psykoanalysen blev kun langsomt optaget i de forskellige miljøer. Borgerskabet og den kommunistiske bevægelse var tilbøjelige til at afvise en teori, der havde fokus på seksualiteten i den grad som psykoanalysen har, og kun i det kulturradikale miljø vandt den umiddelbart gehør.

Dernæst åbner vi for debatten mellem poststrukturalisme og psykoanalyse i forståelsen af kønnet. Indlægget skal ses som en begyndende diskussion parterne imellem, og absolut ikke som en opfordring til at vælge enten eller. I Kirsten Grønbæk Hansens essay præsenteres psykoanalysen som en forståelsesform, der tendentielt foregriber nogle af den senere poststrukturalismes indsigter, og som samtidig gør det muligt at gribe - forsøgsvist og tøvende det "noget" som poststrukturalisterne peger på som det ekskluderede.

I Kirsten Hyldgaards artikel om "Kærlighedens umulighed" bevæger vi os ind i den psykoanalysetolkning, som Lacan udviklede og ind i et af psykoanalysens genkommende temaer: kærligheden. Det diskuteres hvad kærligheden kan være, hvis ikke man vil sejle mellem kynismens Scylla og sentimentalitetens Charybdis. Men kærlighed er at ville have det, den anden ikke har og derfor kan den også ses som en privilegeret erfaring af ophævelse af subjekt og objekt. Kærligheden er årsagsløs, idet der elskes for dette "noget" der ikke er den anden, men noget mere end den anden.

Peter Land har netop haft udstillet sine værker, og derfor får Rune Gades artikel "Horror vacui - om Peter Land og fornedrelsens figur" en særlig aktualitet. I sin analyse af to af Peter Lands værker vises det, hvordan han underminerer de konventionelle dikotome oppositioner mellem kønnene, ved at vrænge af disse - også i den første video, hvor to pornomodeller optræder foran Lands kamera. Ikke bare fordi Land ikke behersker den kønnede rolle, men også fordi der er tale om en aggressiv eksponering af afstanden mellem ideal-jeg og jeg, med tilskueren som ufrivillig voyeur.

Med Lilian Munk Rösings artikel “Kønnets anatomiske metaforer" bevæger vi os igen ind i området mellem essentialisme og konstruktivisme - og tematiserer således indirekte forholdet mellem psykoanalyse og poststrukturalisme. Kroppen forstås som en dialog mellem anatomien og fantasien, og dermed ikke som ren anatomi eller som ren konstruktion. Alting henviser til kroppen, og kroppen henviser altid til noget andet end sig selv. Med dette som udgangspunkt findes og foreslås der metaforer fra den kvindelige anatomi, der byder sig som alternativer til Fallos.

Det sidste bidrag, Rikke Schubarts debatindlæg "Feministen Ilse: Mandlige fantasier og kvindelig ønsketænkning" skriver sig ikke direkte ind i temaet, men berører det dog for så vidt som det handler om de film, der taler mere til lysten og fantasien end til fornuften. Det diskuteres hvilke stereotyper der generelt indgår i film med kvindelige helte og specifikt i filmene om Ilse, som måske ikke kan kaldes heltinde, men dog er den, der for en umiddelbar betragtning ser ud til at have kontrol over situationen.

God læselyst!

Temaredaktør Kirsten Grønbak Hansen 